\title{
THE ELUSIVE GOAL: THE QUEST FOR A CREDIBLE IMMIGRATION POLICY
}

Vernon M. Briggs, Jr.

\section{Pressure for Reform: Over the Long Run}

For more than 30 years the United States has unsuccessfully struggled to reform its often maligned and massively abused immigration policies. Matters went awry following the passage of the Immigration Act of 1965. There were unexpected consequences. Intended to remove the overtly discriminatory features of the "national origins" admissions system in place since the 1920s, the legislation inadvertently ushered in the return of the phenomenon of mass immigration. Neither political party nor any of the advocates for reform in 1965 in either the Johnson Administration or Congress sought such an objective. Indeed, they specifically assured the public that such an outcome was not being sought and promised that it would not happen (Briggs, 2003, pp. 124-130). But it did. Like the proverbial genie in the jug, the change creating forces of mass immigration were once again released on an unsuspecting and unprepared populace. Until rebottled by reform legislation, the process will continue.

Specifically, the Act had no effective measures to enforce its regulatory terms which quickly led to an explosion of illegal immigrants; its new provisions for the admission of a limited number of refugees were quickly swamped by foreign policy decisions related to developments in Cuba and Vietnam and the expanded "family reunification" admissions criterion that added extended family members grossly underestimated the number of eligible persons who would try to avail themselves of the opportunity to immigrate. Thus, inadvertently, the legislation had enacted a new immigration policy that had enormous labor market implications in terms of the numbers of people involved but was essentially oblivious to the human capital endowments (i.e., skills, work experiences, educational attainment or English-speaking abilities) of those who entered.

To be precise, the foreign-born population of the United States in 1965 was 8.5 million people (or 4.4 percent of the population - the lowest rate it had ever been). The foreign-born population had been declining in absolute numbers since 1930 and in percentage terms since 1910. By 2010, the foreign-born population had soared to 40 million persons and was 12.9 percent of the population (Camarota, 2011, p.3). Of this number, 11.2 million persons (or 3.7 percent of the population) were illegal immigrants (Passel \&Cohn, 2011, p.2). 
Some 300,000 to 500,000 illegal immigrants enter the U.S. economy each year, although many voluntarily return to their homelands and others are deported by the federal government each year.

It was also unanticipated by the policymakers in 1965 that most of the countries from which post-1965 immigrants would come would be the less economically developed nations of the world. But it has. As of 2009, 52 percent of the adult foreign-born population of the United States (i.e., persons over the age of 25 years of age) came from Mexico, Central America, South America and the Caribbean region; 24 percent countries in South and East Asia; 3 percent from countries of the Middle East; and 3 percent form Africa (Dockterman, 2011, p.1 and Table 23). Many of the major source countries are among the poorest on the planet where opportunities for education and training are sparse.

Hence, it is not surprising that the most troublesome characteristic of the post1965 wave of mass immigration is the extraordinarily high number of adult immigrants who are poorly educated. As of 2010, 32.3 percent of the foreignborn adult population did not have a high school diploma (compared to 11.4 percent of the native -born adult population). In terms of the labor force, 26.5 percent of the adult labor force in 2010 had not completed high school (compared to 5.4 percent of the native-born adult labor force). This low level of educational attainment explains, in part, the high unemployment rate for adult foreign-born workers of 9.8 percent in 2010 which exceeded the 9.6 percent rate for adult native-born workers (Bureau of Labor Statistics, 2011, p. 2).

As for related labor force data, the foreign-born labor force in 1970 (the closest year to 1965 for which comparable data are available) was composed of 4.3 million workers (or 5.2 percent of the civilian labor force - a percentage that was also the lowest figure in American history) (Bureau of the Census, 2009, p.1). By 2010, the foreign-born workforce had swelled to 24.3 million workers (or 15.8 percent of the civilian labor force) (Bureau of Labor Statistics, May 27, 2011, Table 1). Of that number, 8 million workers (or 5.2 percent of the civilian labor force) were illegal immigrants in 2010 (Passel and Cohn, 2011, p.2). Thus, onethird of the entire foreign-born labor force is composed of illegal immigrant workers.

In passing, it should be noted that immigration policy is the nation's most fundamental labor law. Its provisions serves as a worker protection measure that defines who exactly is legally eligible to be in the labor force. Illegal immigrant workers undermine the rights of those eligible to be in the labor force 
(i.e., citizen workers, permanent resident workers, and foreign workers who hold temporary employment visas) by their competition for job opportunities and they modulate wage rates and income levels by their presence. An illegal practice is, by definition, an unfair practice.

Thus, the long run issues are the sheer scale of the annual immigrant inflow; the widespread abuse of the admissions system by illegal immigrants; and the low human capital attributes of much of the adult immigrant labor force which disproportionately enlarges the low-skilled labor force and worsens the skills mismatch in the labor market.

\section{Pressure for Reform: In the Short Run}

In late 2007 the financial crisis associated with the banking and housing industries hit the U.S. economy. It turned into a full-scale recession that, though technically ending in late-2009, has continued as an anemic economy to this day. The episode has proven to be the most protracted economic downturn the U.S. economy has experienced since the Great Depression.

Persistently high unemployment levels (exceeding 6 percent since August 2008), accompanied by large numbers of workers who are involuntarily working only part-time and others who have become "discouraged" from job seeking, have contributed to either declining or essentially stagnant levels of personal income. Meanwhile, poverty figures have increased and income disparity has widened among families over the interval.

Worst affected has been the plight of low skilled workers - the same group whose wages and employment opportunities have been disproportionately harmed by the shortcomings of prevailing immigration policies. The unemployment rate as of December 2011 for adult workers without high school diplomas was 14.3 percent for all adult workers (24.2 percent for adult AfricanAmerican workers). Immigration policy did not precipitate the economic downturn of this period. But its associated impacts worsen the hardship of needy members of the workforce and exercise a counter-productive influence on national recovery efforts.

As during the depression of the 1930s, unprecedented policy measures were put in place by the Bush and, subsequently, the Obama Administrations between 2007 and 2011. The federal government undertook private sector "bailouts" of failing large enterprises; enacted extensive tax reductions and increased spending measures to stimulate employment; and coordinated these market 
interventions with monetary policy manipulations by the Federal Reserve System that lowered interest rates to previously unimagined levels. It could be expected, given the magnitude of the problems and the scale of these policy responses, that immigration reform would have been included; but it has not.

Indeed, the most distinctive difference between government economic policies during the depression of the 1930s and the downturn of the current era is the role of immigration policy. From 1931-1940, there were only 528,421 legal immigrants over the entire timespan from the whole world. Furthermore, many state and local governments in the United States undertook steps during these years to pressure illegal immigrants to exit their communities and to return to their homelands. (Hoffman, 1978, Chapter 8).

In contrast, over the first decade of the 21st Century, 13.1 million immigrants (legal and illegal) entered the United States despite the fact that the number of employed workers declined by about a million workers over the same period. More specifically, over the years 2008 and 2009 (which is the "official" period of recession) 2.4 million new immigrants (legal and illegal) entered the country while over 8.2 million jobs were lost (Camarota, 2010, p.1).

Thus, during the depression decade, immigration was essentially neutral in its impact on the nation's labor market. Over the first decade of the 21st Century, immigration flows were historically high regardless of the stark reality that employment opportunities were contracting and unemployment was either rising or virtually stagnant at high levels (Camarota, 2011, pp. 3-5).

\section{Confirmation of the Imperative for Policy Reform}

\section{National Commissions}

Because immigration policy is complex and prospective changes often spark public controversies, politicians have historically used national commissions to pave the way before immigration reforms are undertaken. These commissions gather the facts, shape the issue, and offer recommendations. Such a tactic has been again applied to the post-1965 immigration reform experience.

Following passage of the Immigration Act of 1965, congressional hearings, federal enforcement agency reports, and academic articles began to document the fact that mounting numbers of illegal immigrants were making a mockery of the new immigration system. In response, the Carter Administration initiated a legislative package in the August 1977 to remedy the issue. Calling for enhanced border enforcement, it also included unprecedented measures such as making it 
illegal for illegal immigrants to seek work or for employers to hire them; establishing civil and criminal penalties for those employers who do and offering a one-time amnesty for those illegal immigrants in the country who had entered before their employment was specifically banned.

Congress sensed controversy and, instead, passed legislation calling for a review of all aspects of the nation's immigration system. Accordingly, Public Law 95412 was enacted in October 1978 that established the Select Commission on Immigration and Refugee Policy to conduct this study.

The Select Commission issued its final report on March 1, 1981. It stated that "immigration policy is out of control" and that policy makers must face the "reality of limitations on immigration" (Select Commission, 1981, p.2 and 5). It went on to offer a comprehensive set of policy reforms.

Congress, however, found the "comprehensive approach" to immigration reform too difficult to handle despite unsuccessful efforts in 1982 and 1984 to do so. Reluctantly, reform leaders turned to a "piecemeal approach." As the Select Commission had found illegal immigration to be the most egregious violation of public policy, it became the first target. The result was passage of the Immigration Reform and Control Act in November 1986. The Select Commission estimated that there were between 3-6 million illegal immigrants in the economy at the time. Most were offered an opportunity to legalize their status. About 2.7 million of them did so amidst charges of extensive document fraud and lax oversight of the eligibility verification procedures. The employment of illegal immigrants was banned; a system of employer sanctions was created to deter hiring of illegal immigrant workers; and border management measures were strengthened.

The Select Commission specifically warned Congress not to enact an amnesty program until after the employer sanctions provisions program was in effect in order "to make it clear that the United States is determined to curtail new flows of undocumented illegal aliens" (Select Commission, 1981, p. 82). Congress ignored this wise advice in the 1986 legislation. Amnesty was granted but, as experience demonstrated, the deterrent efforts were largely scuttled by a lack of funding, manpower and commitment at the federal level as well as the widespread use of counterfeit documents by illegal immigrants. Thus, illegal immigration continued. 
Believing the "back door" to the U.S. labor market closed, however, Congress enacted the Immigration Act of 1990 that opened the "front door" to more legal immigration. But just to be sure that it had not acted precipitously, the legislation also called for the creation of another public commission to study the impact of immigration policy on the nation's labor force and economy. Known as the U.S. Commission on Immigration Reform (CIR), it issued its final report September 30, 1997 (U.S. Commission, 1997).

In addition to its own fact gathering activities, CIR also requested that the National Research Council (NRC) of the National Academy of Sciences convene a special panel of experts to conduct a data-based study of the contemporary demographic, economic and fiscal impacts of immigration on the United States. The objective was "to lay a scientific foundation for policy making on specific issues" so that CIR could "do its work" (National Research Council, 1997, p. 1).

The NRC study found that the educational attainment levels of post-1965 had steadily declined. Consequently, foreign-born workers, on average, earn less than native-born workers and the gap was widening over time. Immigrant workers from Latin America had the lowest wages of all. There was, however, no evidence of discriminatory wages being paid to immigrant workers. Rather, immigrant workers were paid less because they were, in fact, considerably less skilled than native-born workers. The decline in both skills and wages of the foreign-born workers is attributed to the fact that most immigrant workers come from the poorer nations of the world where education and skill levels are limited.

Consequently, the NRC study found that the large inflow of post-1965 immigrants have caused the low-skilled segment of nation's labor supply to swell in size. Immigrant workers, therefore, increase the competition for jobs in the sector of the labor market that consistently has the highest levels of unemployment while also lowering the wages of the workers (citizens or not) with whom they compete - most especially those of low skill workers.

The chief beneficiaries of the extant immigration system, therefore, are the immigrant workers whose wages and incomes are typically higher in the United States than in their homelands and U.S. employers who are able to hire workers at wage levels lower than they would otherwise be. Consumers benefit from lower prices caused by the suppression of worker wages but, when spread across the economy as a whole, the gain is essentially insignificant. 
But there is no question who loses: it is the native-born workers who are low skilled (disproportionately minority, women and youths) and the American taxpayers. The NRC study documented the fact that the fiscal costs of immigration (e.g., education, welfare, incarceration, housing, and health care) far exceeded the taxes paid by the foreign-born population leaving the nativeborn population to pick-up the deficit.

Based upon the NRC input and its own work, CIR's central conclusion was that the nation's immigration system does not function in a vacuum. There are economic consequences associated with policies that affect the size and skill composition of the nation's labor supply. The Report states that policy makers "must give due consideration to shifting economic realities" when they approach the subject of immigration reform. CIR, therefore, found that the reform of existing policies will require "a significant redefinition of priorities" for admitting legal immigrants while also recognizing that curtailing illegal immigration is the "most immediate need" for policy remediation.

State Government Actions

Since the U.S. Supreme Court resolved the issue in the late $19^{\text {th }}$ Century, the federal government has had the responsibility for enacting and enforcing the nation's immigration laws (Briggs, 2003, pp.76-78). But what happens when the federal government fails to perform its obligation? Can state and local governments, who bear most of the direct fiscal costs of illegal immigration, assist in the enforcement of federal laws?

Responding to widespread public frustration, several states have taken matters into their own hands. In April 2010, Arizona enacted legislation that defined a variety of federal immigration-related actions as state offenses and indicated how local officials could enforce these laws. Immigrants would be required to carry their papers with them at all times and it would be illegal for illegal immigrants to work or for employers to hire them. Legislators claim they just copied the federal law pertaining to these matters and added some enforcement teeth. They deny that the state sought to usurp federal law.

The most controversial section pertained to a requirement that police question persons who had been stopped for other reasons about their immigration status. If they had reasonable suspicion they might be illegal immigrants, they could be detained. Critics claimed the law was an invitation to racial profiling and the U.S. Appeals Court for the Ninth Circuit agreed in April 2011. Arizona appealed to the 
U.S. Supreme Court which accepted the case and is expected to rule sometime in 2012.

State governments in South Carolina, Georgia, Louisiana, Tennessee, Utah, and Alabama also enacted a variety laws in 2011 seeking to stem the flow of illegal immigrants. All have large numbers of low-skilled workers, many of whom are poor, unemployed and from minority groups. These state laws vary in their terms but have a common objective: make them less attractive job magnets for illegal immigrants.

Some portions of these state laws have been struck down by federal courts; some are on appeal. But one of the most common provisions that has been allowed to go into effect are state laws mandating the use of the E-Verify (Employment Eligibility Verification) system created by the federal government for voluntary use nationwide by employers. Under this system, employers enter information about job candidates into a data system in order to compare it with information that the federal government already has on file with the Social Security Administration and the Department of Homeland Security. Employers are then told whether the job candidate is authorized to work. The E-Verify system, however, only validates the authenticity of documents; it does not certify that the person is who the documents say he or she is. E-Verify helps but does not solve the problem.

Until clarified by the courts, it is not possible to assess the effectiveness of these state actions. Their real significance rests with the fact that they are manifestations of the widespread frustration of the citizenry with the failure of the federal government to manage the nation's immigration system.

\section{Needed Reforms}

The starting point for all immigration reform efforts must be making the immigration system enforceable. Nothing else makes sense. Otherwise, immigration policy is on a squirrel wheel going nowhere. Illegal immigrants will keep coming in defiance of its terms.

As CIR stated, "a comprehensive strategy" is needed to combat illegal immigration. It will require enhanced border and visa management to reduce both illegal entries and visa "overstayers"; a commitment to strict enforcement of employer sanctions at worksites; and the speedy removal of apprehended illegal immigrants from the country. Adherence to these enforcement practices (and not enacting anymore amnesty programs) would improve the employment 
situation for citizen workers (i.e., especially those who are low-skilled) and reduce the nation's unemployment rate.

As for legal immigration, CIR called for changes to the existing admission system so as to reduce the inflow of so many poorly educated and unskilled adults. To accomplish this feat, CIR stated that the focus of the present legal admission system should both be "shifted away from the extended family and toward the nuclear family and away from the unskilled and toward the higher-skilled immigrant" ( U.S. Commission, 1997, p. XVII).

Thus, unless there is "a compelling" national reason to do so (as is the case for the admission of immediate family members - spouses, minor children, and elderly parents - of U.S. citizens as well as those of refugees), the other familybased admission categories in the existing system should be eliminated. Specifically, these categories are: adult unmarried sons and daughters of U.S. citizens; adult unmarried sons and daughters of legal permanent residents; and adult brothers and sisters of U.S. citizens. Also, under the existing employmentbased admission category, the provision for the admission of 10,000 unskilled workers a year should also be eliminated-- opening these slots to higher skilled immigrants. The United States already has a vast surplus of unskilled workers as their high unemployment rate clearly attests. They do not need more competitors for jobs.

Furthermore, CIR recommended elimination of the admission category for "diversity immigrants" (i.e., about 50,000 immigrants a year who are selected by a lottery from a pool of applicants from countries with low numbers of immigrants over the preceding 5 years). The only human capital qualification to be in this pool is that each person be at least 18 years old and have a high school diploma.

$\mathrm{CIR}$ also recommended that the number of refugees each year be capped at 50,000 persons. The number is usually higher. It is variable as it is set annually by the President and after consultation with Congress. Obviously, there is no human capital requirement for refugees. Most come from less developed countries and most have low levels of human capital. When they enter the labor market, they usually compete for low skilled jobs.

As for what not to do, both the Select Commission and CIR were adamant in their opposition to the inclusion of any "guestworker" programs for less skilled foreign workers. Prior experience has demonstrated that they depress wages 
for citizen workers; stigmatize certain low skilled occupations; are difficult to administer; hard to stop; disrupt local community services; and encourage illegal immigration.

As for any amnesty (or "pathway to citizenship") for illegal immigrants already in the country, there have been seven amnesties since the initial one in 1986 that have legalized the status of an estimated 6 million people - most of whom entered the low skilled labor market. With 11.2 million illegal immigrants presently in the country, past amnesties have clearly not stopped illegal immigration. Instead, as the Select Commission warned when it cautiously recommended the first one, such programs could stimulate more illegal immigration. If there was lax enforcement in the future - as there has been, subsequent illegal immigrants would likely feel that they too are entitled to a legalization pathway. Hence, it is worthy of note that there was no mention among CIR's recommendations for another amnesty program.

Implementing CIR's recommendations, therefore, would lower the inflow of legal immigrants by about $30 \%$ a year (thereby decreasing the size of the labor supply). This scale reduction, plus any further decline caused by reducing the number of illegal immigrants and accepting its refugee ceiling, would collectively improve the skill composition of the labor supply (by reducing the ranks of low skilled workers). In the process, these reforms would help the nation achieve it broader economic objectives of reducing both the levels of unemployment and poverty while simultaneously assisting needy members of the low skilled labor force to find work and to raise their incomes.

\section{References}

Briggs, Jr., V.M. (2003). Mass Immigration and the National Interest. Armonk, NY: M. E. Sharpe

Bureau of the Census. (2009). The Foreign-Born Labor Force of the United States: 2007. Washington, DC: U.S. Department of Commerce.

Bureau of Labor Statistics. (2011). Foreign-Born Workers: Labor Force Characteristics - 2010. Washington, DC: U.S. Department of Labor.

Camarota, S.A. (2010). Immigration and Economic Stagnation: Backgrounder. Washington DC: Center for Immigration Studies.

. (2011). A Record-Setting Decade of Immigration: 2000-2010.

Washington, DC: Center for Immigration Studies. 
Dockterman, D. (2011). Statistical Portrait of the Foreign-Born Population in the United States, 2009. Washington, DC: Pew Hispanic Center.

Hoffman, A. (1978). Mexican Repatriation During the Great Depression: A Reappraisal. A. Corwin (Ed.), Immigrants - and Immigrants: Perspectives on Mexican Labor Migration to the United States. Westport, CN: Greenwood Press. National Research Council. (1997). The New Americans: Economic, Demographic and Fiscal Effects of Immigration. Washington, DC: The National Academy Press.

Select Commission on Immigration and Refugee Policy. (1981). U.S. Immigration Policy and the National Interest. Washington DC: Select Commission on Immigration and Refugee Policy.

Passel, J.S. \& Cohn, D. (2011). Unauthorized Immigrant Population: National and State Trends, 2010. Washington, DC: Pew Hispanic Center.

U.S. Commission on Immigration Reform. (1997). Becoming An American: Immigration Policy and Immigrant Policy. Washington, DC: U.S. Commission of Immigration Reform. 